\title{
Induction and Cytological Studies of Coffea arabica cv. Catimor CIFC 7963 Callus
}

\author{
Sirada Katnim and Noppamart Lokkamlue*
}

\begin{abstract}
Department of Genetics, Faculty of Liberal Arts and Science, Kasetsart University Kamphaeng Saen Campus, Nakhon Pathom 73140, Thailand

*Corresponding author.E-mail: faasnmlo@ku.ac.th https://doi.org/10.12982/CMUJNS.2020.0027
\end{abstract}

Received: March 7, 2019

Revised: May 17, 2019

Accepted: August 26, 2019

\begin{abstract}
This study investigated the effect of activated charcoal (AC) and 4amino-3,5,6-trichloro-2-pyridinecarboxylic acid (picloram) on callus induction and occurrence of mitotic aberrations in coffee cells. Explants from the first pair of expanded leaves (1 ${ }^{\text {st }}$ leaves) of Coffea arabica "Catimor CIFC 7963" were cultured on Murashige and Skoog (MS) medium supplemented with $1 \mu M$ 2,4-dichlorophenoxyacetic acid (2,4-D) + $5 \mu M$ 6-benzlyaminopurine (BA). The treatments included the following rates of AC application: $0.008 \%, 0.08 \%$, $0.1 \%$, and $1 \%(w / v)$. We also evaluated the effects of growth in MS medium supplemented with $1 \mu M 2,4-D+5 \mu M B A+10 \mathrm{mM}$ picloram vs. $10 \mathrm{mM}$ picloram as the sole plant growth regulator. The results showed that cells of the $1^{\text {st }}$ leaves on MS medium $+1 \mu M 2,4-D+5 \mu M B A+0.008 \%$ AC were induced to callus (46.88\% callus induction). In addition, callus induction $(90.63 \%$ and $59.38 \%$ ) was observed in the leaves cultured on MS medium $+1 \mu M 2,4-D+5$ $\mu M B A+10 \mathrm{mM}$ picloram and on MS medium $+10 \mathrm{mM}$ picloram, respectively. However, the 4-month-old friable calli developed on MS medium containing picloram showed mitotic aberrations. Some of these included binucleated cells, a micronucleus in binucleated cells, and vagrant chromosome cells. These results highlight that both $0.008 \% \mathrm{AC}$ and $10 \mathrm{mM}$ picloram were able to induce the development of 4-month-old friable callus in a high proportion of $C$. arabica "Catimor CIFC 7963" cells, but while the former produced no mitotic aberrations, the latter induced mitotic aberrations in cells.
\end{abstract}

Keywords: Coffea arabica, Mitotic aberration, Friable callus, Picloram, Activated charcoal 


\section{INTRODUCTION}

Coffea arabica "Catimor CIFC 7963" is a hybrid coffee plant, obtained by crossing C. arabica "Caturra rojo" with a hybrid of Timor (a natural cross of C. arabica and C. canephora) (Silva et al., 2005). It is a self-fertilizing species (tetraploid plant, $2 \mathrm{n}=4 \mathrm{x}=44$ ) (Etienne and Bertrand, 2003). Propagation of coffee plants via vegetative organs provides true-to-type regenerated plants. In addition, micropropagation using somatic embryogenesis can facilitate largescale vegetative propagation of hybrid varieties in clonal form. However, during this process, the polyploid cells may undergo abnormal division and generate aneuploid cells in polyploid plants. Chromosome segregation errors can result from changes in the relative dosage of products of genes located on the mis-segregated chromosomes (Potapova and Gorbsky, 2017). Thus, successful mass production of embryogenic cells and somatic embryos (SEs) is contingent on the genetic stability of regenerated plants. Embryogenic coffee cells are frequently generated using older embryogenic cultures, and hence, the phenotypic variants due to aneuploidy can be passed on through mitotic aberrations in cells. It has been demonstrated that the chromosomal variability is directly linked to somaclonal variation (SV) in embryogenic coffee cells (Etienne et al., 2016). SV is described as the phenotypic variation observed during the clonal propagation of plants. It is a major cause of concern when strict clonal propagation of elite plants is required to ensure true-to-type in vitro propagation.

Arabica coffee hybrid plants should be studied for multiplication using somatic embryogenesis processes, as it can help achieve: (1) a reduction in production costs, and (2) a guarantee that the propagated plants are true-to-type (Etienne and Bertrand, 2003). In particular, the use of embryogenic callus has been frequently associated with an increase in genetic instability and SV in the regenerated plants (Jähne et al., 1991; Rival et al., 1997; Lu et al., 2006). The SV in embryogenic-cell-derived plants is probably related to the use of 2, 4-D for division of cells in an embryogenic undifferentiated state (Lambé et al., 1997; Von Aderkas and Bonga, 2000). In addition, picloram, which works as an auxin, can stimulate DNA and RNA synthesis along with the transcription of variable proteins in plants, resulting in uncontrolled cell division to induce plant callus formation (Ozel et al., 2018). However, the uncontrolled cell division is associated with incomplete replication of the genome, and can lead to chromosomal aberrations (Arora et al., 2013). The frequency of SV has been shown to increase exponentially with the age of the embryogenic cell culture (Etienne and Bertrand, 2003). The types of phenotypic variants observed in coffee plants have been characterized based on the color of juvenile leaves, giant, dwarf, and thick leaves (bullata), variegata, angustifolia, and multi-stems. These variants were rare $(1.3 \%)$ for plants derived from embryogenic callus in 3-month-old embryogenic cell suspensions. However, the frequency of variants produced from 
6-, 9-, and 12-month-old cell suspensions was $6 \%, 10 \%$, and $25 \%$, respectively (Etienne and Bertrand, 2003). Thus, the multiplication time for embryogenic cells culture was shortened to 6 months and the level of auxin was reduced (0-1.4 $\mu \mathrm{M}$ $2,4-\mathrm{D})$, as the frequency of variation is affected by these parameters.

Chromosomal variability can also be a source of SV. A cytological technique has been used to quantify the SV and genetic stability of plants derived from a tissue culture system (Raha and Roy, 2003). In addition, variation in plant tissue culture, particularly in callus cultures, can also be caused by mitotic aberrations (Larkin and Scowcroft, 1981). In this present study, the mitotic aberrations in leaf embryogenic callus cultures were investigated. Activated charcoal (AC) promotes embryogenesis, and improves the growth and morphogenic responses of explant. AC adsorbs many impurities, and modulates the culture medium $\mathrm{pH}$ by altering the mineral availability in the culture medium, in order to induce embryogenesis (Chee and Tricoli 1988; Van Winkle and Pullman 2003; Van Winkle et al., 2003; Thomas, 2008; Sáenz et al. 2010; Cheng et al., 2013). Thus, a selected leaf explant from C. arabica "Catimor CIFC 7963" was used to study the effects of treatment with various concentrations of $\mathrm{AC}$ and plant growth regulators for various durations of callus culture. In addition, we carried out a morphological characterization of the callus initiated from leaf sections, and studied the callus induction as well. The purpose of this study was to evaluate the optimal culture age of C. arabica "Catimor CIFC 7963", and the cytotoxicity of picloram on mitotic divisions of embryogenic callus, for true-totype propagation.

\section{MATERIALS AND METHODS}

\section{Plant preparation and tissue culture}

A sample of 32 explants of leaves from greenhouse-grown 2-year-old coffee trees (C. arabica "Catimor CIFC 7963") were used for callus induction. All explants from the basal part of the leaf were washed under running tap water for $5 \mathrm{~min}$ to remove dust particles. The explants were then disinfected for $10 \mathrm{~min}$ in a $15 \%(\mathrm{w} / \mathrm{v})$ solution of commercial bleach $(\mathrm{NaOCl})$ containing a few drops of Tween 80 (Merk Schuchardt), followed by three successive washes with sterile double distilled water to remove all traces of $\mathrm{NaOCl}$. After surface sterilization, the margin and the midrib of each leaf were removed and the remaining leaf tissue was cut into pieces of size $1 \mathrm{~cm} \times 1 \mathrm{~cm}$. The sterilized explants were placed on MS medium (Murashige and Skoog, 1962), supplemented with picloram and acid-washed AC, for plant tissue culture (Phytotechnology Laboratories ${ }^{\circledR}$ ), combined with or without 2,4-D and BA. Eight treatments were used to evaluate the effects of the plant growth regulators $(2,4-\mathrm{D}$ and $\mathrm{BA}(\mu \mathrm{M})$, picloram $(\mathrm{mM})$, and $\mathrm{AC}(\mathrm{w} / \mathrm{v}) \%)$ as follows: treatment $\mathrm{A}: 0$ 2,4-D, 0 BA, 0 picloram, $0 \mathrm{AC}$, treatment B: $12,4-\mathrm{D}, 5 \mathrm{BA}$, treatment C: $12,4-\mathrm{D}, 5 \mathrm{BA}, 0.008 \mathrm{AC}$, treatment D: 1 2,4-D, 5 BA, 0.08 AC, treatment E: 1 2,4-D, 5 BA, 0.8 AC, treatment F: 
1 2,4-D, 5 BA, 1 AC, treatment G: 1 2,4-D, 5 BA, 10 picloram, and treatment $\mathrm{H}$ : 0 2,4-D, 0 BA, 10 picloram. All media were adjusted to $\mathrm{pH}$ 5.7-5.8. The cultures were incubated in the dark at $25 \pm 2{ }^{\circ} \mathrm{C}$ and subcultured at 4 -week intervals on the same media for 4 months. Subsequently, the numbers of explants with calli were counted, and the percentage of explants with calli was calculated using the formula:

Percentage of explants with calli $=\frac{\text { Number of explants with calli }}{\text { Total number of explants }} \times 100$

After 4 months, the calli were examined and the fresh weight per explant was determined before investing the cytological behaviors.

\section{Chromosome squash}

After 2 and 4 months, the calli were subjected to cytological analysis. They were kept in Carnoy's solution (absolute alcohol:glacial acetic acid, 3:1) for $24 \mathrm{~h}$ and then stored in $70 \%$ ethyl alcohol at $4{ }^{\circ} \mathrm{C}$ until analysis. The cell walls of the calli were hydrolyzed in $1 \mathrm{~N} \mathrm{HCl}$ for $15 \mathrm{~min}$ and then stained in $1 \%$ aceto-orcein for $10 \mathrm{~min}$ before the tissue was squashed under a coverslip. The mitotic stages in the calli cells were observed under a light microscope (Olympus Optical Co., Ltd) using a 100x objective lens in immersion oil. Selected representative stages of cells were photographed. The normal and abnormal cells were then analyzed. The mitotic index (MI) was calculated using the formula:

$$
\text { Mitotic index }(\mathrm{MI})=\frac{\text { Number of dividing cells }}{\text { Total number of cells scored }} \times 100
$$

\section{Statistical analysis}

Data were analyzed using one-way ANOVA, and significance differences among treatment means were determined using Duncan's multiple range test at $P<0.05$. The statistical package for SPSS version 14.0 software was used (Freund and Wilson, 2003).

\section{RESULTS}

Effects of $\mathrm{AC}$ on cell proliferation and callus induction in $C$. arabica "Catimor CIFC 7963" leaf explants

In treatments B and C, calli were obtained from leaf explants after 1 month, while in treatments A (control), D, and E, groups of small cells were obtained. While cell division was induced in all leaf sections of these three treatments, the fresh weight could not be examined due to insufficient proliferation. Our results showed that none of the groups of small cells (treatments A, D, and E) showed 
continuous development to callus after 2 months. Furthermore, in treatment F, some explants showed no response and exhibited necrosis after 2 months. This result revealed that increasing the concentration of $\mathrm{AC}$ beyond $0.08 \%(\mathrm{w} / \mathrm{v})$, to $0.01 \%$ or $1 \%$, resulted in decreased cell proliferation into callus formation among the surviving explants. The highest percentage of callus induction $(100 \%)$ on medium was obtained for explants $(0.20 \pm 0.07 \mathrm{~g} / \mathrm{explant})$ cultured on MS medium supplemented with $1 \mu \mathrm{M} 2,4-\mathrm{D}+5 \mu \mathrm{M}$ BA (treatment B). Moreover, the addition of $0.008 \%$ AC resulted in no significant difference in the fresh weight of 4-month-old calli ( $0.18 \pm 0.07 \mathrm{~g} /$ explant $)$, but did induce friable calli in all the explants. We found that both compact and friable calli were obtained after 2-4 months on MS medium supplemented with 2,4-D + BA (treatment B). Interestingly, the MS medium supplemented with 2,4-D + BA containing $0.008 \%$ AC induced only friable calli from explants (Table 1). This result indicated that AC had a significant effect on the development of friable calli.

Table 1. Effects of AC on cell proliferation and callus induction in C. arabica "Catimor CIFC 7963" leaf explants.

\begin{tabular}{|c|c|c|c|c|c|c|}
\hline \multirow{2}{*}{$\begin{array}{c}\text { MS } \\
\text { medium }\end{array}$} & \multicolumn{2}{|c|}{ Supplement } & \multirow{2}{*}{$\begin{array}{c}\mathrm{AC} \\
(\% \mathrm{w} / \mathrm{v})\end{array}$} & \multirow{2}{*}{$\begin{array}{c}\text { Percentage } \\
\text { of callus } \\
\text { induction } \\
(\%)\end{array}$} & \multicolumn{2}{|c|}{ Callus (4 months old) } \\
\hline & $\begin{array}{r}2,4-D \\
(\mu M)\end{array}$ & $\begin{array}{c}\mathbf{B A} \\
(\boldsymbol{\mu M})\end{array}$ & & & $\begin{array}{c}\text { Fresh weight } \\
\text { (g/explant) }\end{array}$ & Callus type \\
\hline $\mathrm{A}$ & - & - & - & $56.25^{b}$ & $-*$ & $\begin{array}{l}\text { group of small } \\
\text { cells }\end{array}$ \\
\hline B & 1 & 5 & - & $100^{\mathrm{a}}$ & $0.20 \pm 0.07^{\mathrm{a}}$ & $\begin{array}{l}\text { compact callus/ } \\
\text { friable callus }\end{array}$ \\
\hline $\mathrm{C}$ & 1 & 5 & 0.008 & $46.88^{b}$ & $0.18 \pm 0.07^{\mathrm{a}}$ & friable callus \\
\hline $\mathrm{D}$ & 1 & 5 & 0.08 & $15.63^{\mathrm{c}}$ & $-*$ & $\begin{array}{l}\text { group of small } \\
\text { cells }\end{array}$ \\
\hline $\mathrm{E}$ & 1 & 5 & 0.1 & $6.25^{\mathrm{cd}}$ & $-*$ & $\begin{array}{l}\text { group of small } \\
\text { cells }\end{array}$ \\
\hline $\mathrm{F}$ & 1 & 5 & 1 & $0^{\mathrm{d}}$ & -* & - \\
\hline
\end{tabular}




\section{Effects of picloram with or without 2, 4-D and BA on callus induction in} C. arabica "Catimor CIFC 7963" leaf explants

Calli from leaf explants were obtained in treatments $B, G$, and $\mathrm{H}$. Moreover, the MS medium supplemented with $10 \mathrm{mM}$ picloram with or without $1 \mu \mathrm{M} 2,4-\mathrm{D}+5 \mu \mathrm{M}$ BA (treatments $\mathrm{G}$ and $\mathrm{H}$, respectively) had a significant effect on the development of friable callus. The highest fresh weight of 4-monthold callus $(0.32 \pm 0.06 \mathrm{~g}$ /explant $)$ was obtained on MS medium supplemented with $1 \mu \mathrm{M} 2,4-\mathrm{D}+5 \mu \mathrm{M}$ BA containing $10 \mathrm{mM}$ picloram (treatment $\mathrm{G}$ ). Moreover, the addition of $10 \mathrm{mM}$ picloram in MS medium supplemented with $1 \mu \mathrm{M} 2,4-\mathrm{D}+5 \mu \mathrm{M}$ BA resulted in no significant effect on callus induction $(90.63 \%)$, but picloram did show a significant effect on the fresh weight of callus. The fresh weight of callus obtained with the combination of 2, 4-D + BA was not significantly different from that obtained with picloram as the sole plant growth regulator, indicating that the effect of picloram as auxin was similar to that of 2, 4-D in callus induction. Our results showed that the picloram also affected the cell division, without any cytokinin application, in treatment H. However, cells of the leaf explants developed into friable calli, resulting in reduced callus induction $(59.38 \%)$ and reduced fresh weight of callus $(0.13 \pm 0.05 \mathrm{~g} / \mathrm{explant})$ (Table 2). The calli from treatments B, C, G, and $\mathrm{H}$ were fixed in Carnoy's solution to investigate their cytological behavior.

Table 2. Effects of picloram with or without 2, 4-D and BA on callus induction in C. arabica "Catimor CIFC 7963" leaf explants.

\begin{tabular}{|c|c|c|c|c|c|c|}
\hline \multirow{2}{*}{$\begin{array}{c}\text { MS } \\
\text { medium }\end{array}$} & \multicolumn{2}{|c|}{ Supplement } & \multirow{2}{*}{$\begin{array}{c}\text { Picloram } \\
(\mathrm{mM}) \\
(\%)\end{array}$} & \multirow{2}{*}{$\begin{array}{c}\text { Percentage } \\
\text { of callus } \\
\text { induction } \\
(\%)\end{array}$} & \multicolumn{2}{|c|}{ Callus (4 months old) } \\
\hline & $\begin{array}{l}\text { 2,4-D } \\
(\mu \mathrm{M})\end{array}$ & $\begin{array}{c}\text { BA } \\
(\mu \mathrm{M})\end{array}$ & & & $\begin{array}{l}\text { Fresh weight } \\
\text { (g/explant) }\end{array}$ & Callus type \\
\hline $\mathrm{A}$ & - & - & - & $56.25^{\mathrm{b}}$ & $-*$ & $\begin{array}{l}\text { group of small } \\
\text { cells }\end{array}$ \\
\hline B & 1 & 5 & - & $100^{\mathrm{a}}$ & $0.20 \pm 0.07^{b}$ & $\begin{array}{l}\text { compact callus/ } \\
\text { friable callus }\end{array}$ \\
\hline G & 1 & 5 & 10 & $90.63^{\mathrm{a}}$ & $0.32 \pm 0.06^{\mathrm{a}}$ & friable callus \\
\hline $\mathrm{H}$ & - & - & 10 & $59.38^{\mathrm{b}}$ & $0.13 \pm 0.05^{\mathrm{b}}$ & friable callus \\
\hline
\end{tabular}




\section{Callus characterization of $C$. arabica "Catimor CIFC 7963" (2 and 4 months old)}

All calli were cultured on media for 2-4 months. At the end of the second month, the green calli presented a white yellowish color in treatments B and C (Figure 1A and 1B). Thereafter, up to 4 months, the calli presented a black brownish color (Figure 1E and 1F). Asynchronous development of SEs was observed under the stereo microscope. Different stages of SEs, including globular embryos and elongated embryos, were clearly visible within 2 months in treatments B and C (Figure 1A and 1B). Treatment B and C not only produced SEs, but also produced roots via indirect organogenesis within 2 months (Figure 1A-B and 1E-F). Treatments $\mathrm{G}$ and $\mathrm{H}$ showed no established SEs. Our results revealed that $\mathrm{AC}$ and picloram produced more developed and larger sized friable calli, respectively. Moreover, the white friable calli of treatments $\mathrm{G}$ and $\mathrm{H}$ showed no color change even after 4 months (Figure $1 \mathrm{C}-\mathrm{D}$ and $1 \mathrm{G}-\mathrm{H}$ ).

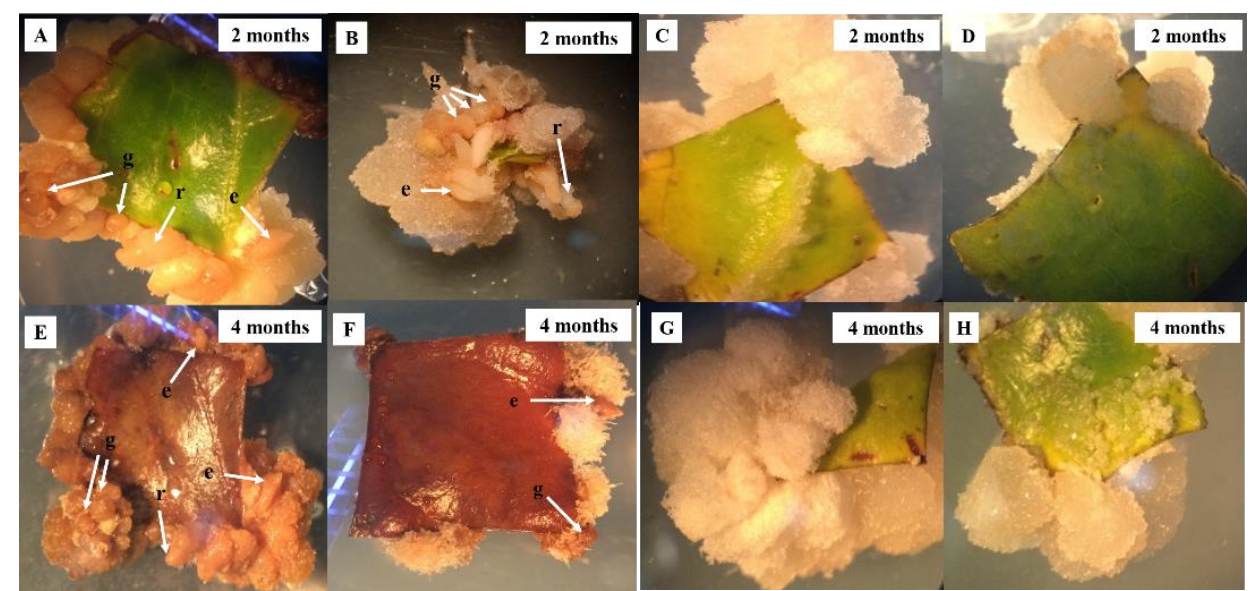

Figure 1. Callus of C. arabica "Catimor CIFC 7963" on media at 2 and 4 months. (A, E) MS medium + 1 $\mathrm{MM} 2,4-\mathrm{D}+5 \mu \mathrm{M}$ BA, (g) globular embryo (e) elongate embryo (r) root. (B, F) MS medium $+1 \mu \mathrm{M} 2,4-\mathrm{D}+5 \mu \mathrm{M}$ $\mathrm{BA}+0.008 \% \mathrm{AC}(\mathrm{w} / \mathrm{v}) .(\mathrm{C}, \mathrm{G}) \mathrm{MS}$ medium $+1 \mu \mathrm{M} 2,4-\mathrm{D}+5 \mu \mathrm{M}$ $\mathrm{BA}+10 \mathrm{mM}$ picloram. $(\mathrm{D}, \mathrm{H}) \mathrm{MS}$ medium $+10 \mathrm{mM}$ picloram.

\section{Cytological study of calli cells ( 2 and 4 months old)}

Mitotic division was observed every 2 months for the calli cells cultured on the four media (treatments B, C, G, and H). Cytological analysis showed 1,829 actively dividing cells ( 2 months old) at various stages of mitosis (interphase, prophase, metaphase, anaphase, and telophase), as shown in Figure 2A-E. The calli contained several types of cells, including those both round and elongated ones. Moreover, cytokinesis was observed, where the cell divided to form two daughter cells. The dividing structure, known as the cell plate, formed in the center of the cytoplasm, and a new cell wall developed between the two daughter cells (Figure 2F). Our results showed that $10 \mathrm{mM}$ picloram in combination with 
$1 \mu \mathrm{M} 2,4-\mathrm{D}+5 \mu \mathrm{m}$ BA (treatment $\mathrm{G}$ ) induced the highest fresh weight of callus/explant $(0.32 \pm 0.06 \mathrm{~g} / \mathrm{explant})$ (Table 2$)$. This phenomenon caused mitotic aberrations in the 4-month-old calli. The results showed that almost 2,337 calli cells (4 months old) had normally dividing nuclei, with treatments B and C showing no abnormal calli cells. In contrast, binucleated cells were observed in MS medium containing $1 \mu \mathrm{M} 2,4-\mathrm{D}+5 \mu \mathrm{m} \mathrm{BA}+10 \mathrm{mM}$ picloram (treatment $\mathrm{G})$. In binucleated cells, the nuclei were typically of the same size, owing to the inhibition of cell plate formation (Figure 2G). In addition, micronuclei in binucleated cells and vagrant chromosome cells, as a consequence of spindle poisoning, were observed in MS medium containing only $10 \mathrm{mM}$ picloram (treatment H) (Figure 2 G-I). The percentage of these abnormal cells was low (1\%, data not shown). The natural consequence of such abnormality was genetic mosaicism of the callus. The cells observed develop into polyploid and aneuploid plants. This result suggested that $10 \mathrm{mM}$ picloram had significant effects on mitotic aberration in the cells of 4-month-old calli, and a higher number of polyploid and aneuploid cells were seen with increasing age of the culture.

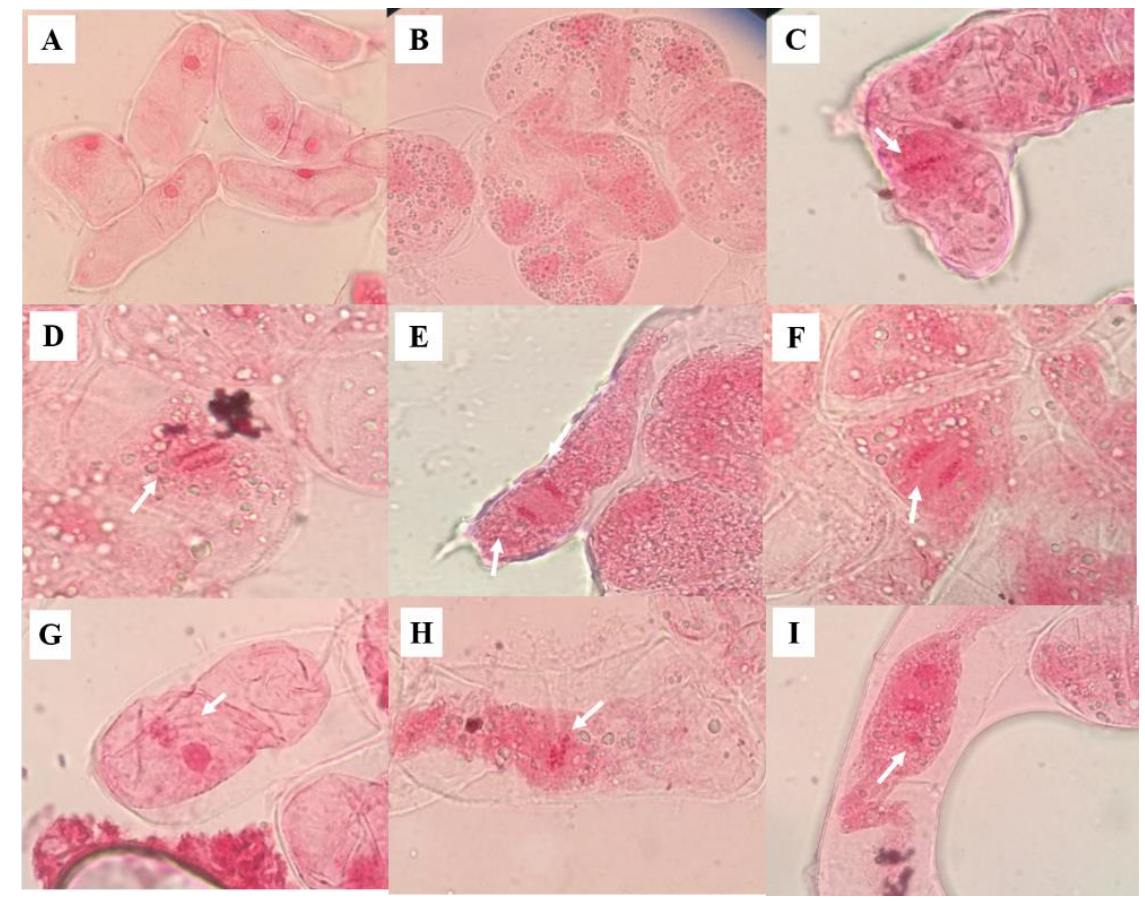

Figure 2. Normal and abnormal calli cells. (A) Interphase (100x), (B) prophase (100x), (C) metaphase (100x), (D) anaphase (100x), (E) telophase (100x), (F) cytokinesis (100x), (G) binucleated cell (100x), (H) vagrant chromosome cell (100x), and (I) micronucleus in binucleated cell (100x).

\section{MI study of calli cells ( 2 and 4 months old)}

As for the distribution of cells across the mitotic phases, the highest number of cells was seen in prophase. The number of calli cells in metaphase, anaphase, 
and telophase decreased on all media (Table 3). Cytological analysis revealed normal mitotic activity in 2-month-old calli cells (Figure 2A-E), whereas the 4-month-old calli cells in treatments $\mathrm{G}$ and $\mathrm{H}$ showed mitotic aberrations (Figure $2 \mathrm{G}-\mathrm{H}$ ), with a rather low $\mathrm{MI}$ in treatment $\mathrm{C}(8.46)$ but a higher MI value in treatment B (4.62) (Table 3). The MI was lower in 4-month-old calli cells compared with the 2-month-old calli cells in treatments G (4.90 and 4.96, respectively) and $\mathrm{H}$ (4.74 and 4.82, respectively). This result revealed that aging of the cell culture on medium containing $10 \mathrm{mM}$ picloram was mutagenic in coffee, as there was a reduction in the MI of the 4-month-old calli cells. In contrast, treatments B and C resulted in an MI increase in the 4-month-old calli cells compared with the 2-month-old calli cells (4.62 and 2.66, respectively) and (8.46 and 4.41, respectively) (Table 3 ), and they showed normal mitotic division (Figure 2A-E). Moreover, we found that the presence of auxin at a low level $(1 \mu \mathrm{M} 2,4-\mathrm{D})$ in treatments $\mathrm{B}$ and $\mathrm{C}$ resulted in organized, normal growth phases in the callus, with no mitotic aberrations.

Table 3. MI and number of calli cells ( 2 and 4 months old) undergoing mitotic division in C. arabica "Catimor CIFC 7963".

\begin{tabular}{|c|c|c|c|c|c|c|c|}
\hline \multirow{4}{*}{ 急 } & \multirow{2}{*}{ 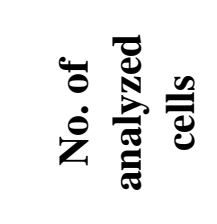 } & \multirow{2}{*}{ 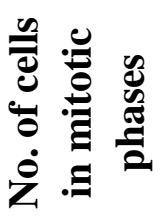 } & \multirow{2}{*}{$\sum$} & \multicolumn{4}{|c|}{ No. of cells by mitotic phases } \\
\hline & & & & Prophase & Metaphase & Anaphase & Telophase \\
\hline & $2 / 4$ & $2 / 4$ & $2 / 4$ & $2 / 4$ & $2 / 4$ & $2 / 4$ & $2 / 4$ \\
\hline & months old & $\begin{array}{c}\text { months } \\
\text { old }\end{array}$ & $\begin{array}{l}\text { months } \\
\text { old }\end{array}$ & months old & $\begin{array}{c}\text { months } \\
\text { old }\end{array}$ & months old & months old \\
\hline $\mathrm{B}$ & $489 / 606$ & $13 / 28$ & $2.66 / 4.62$ & $5 / 25$ & $3 / 2$ & $2 / 1$ & $3 / 0$ \\
\hline $\mathrm{C}$ & $340 / 544$ & $15 / 46$ & $4.41 / 8.46$ & $7 / 45$ & $4 / 1$ & $3 / 0$ & $1 / 0$ \\
\hline $\mathrm{G}$ & $524 / 469$ & $26 / 23$ & $4.96 / 4.90$ & $18 / 18$ & $3 / 2$ & $2 / 1$ & $3 / 2$ \\
\hline $\mathrm{H}$ & $539 / 718$ & $26 / 34$ & $4.82 / 4.74$ & $20 / 30$ & $2 / 1$ & $2 / 2$ & $2 / 1$ \\
\hline
\end{tabular}

\section{DISCUSSION}

Effects of $\mathrm{AC}$ on cell proliferation and callus induction in $C$. arabica "Catimor CIFC 7963" leaf explants

The callus induction in the treatment with $1 \mu \mathrm{M} 2,4-\mathrm{D}+5 \mu \mathrm{M} \mathrm{BA}+$ $0.008 \% \mathrm{AC}(\mathrm{w} / \mathrm{v})$ did not differ significantly from the one with $1 \mu \mathrm{M} 2,4-\mathrm{D}+5$ $\mu \mathrm{M}$ BA treatment (without the AC). Interestingly, AC at $0.008 \%$ had a high rate of induction of only friable calli from explants, in contrast with the medium 
containing 2,4-D + BA, which produced both compact and friable calli (Table 1). These results support the finding from a previous study that $\mathrm{AC}$ at a concentration of $0.05 \%(\mathrm{w} / \mathrm{v})$ can act as a promoter of embryogenesis in different genotypes of pepper (Cheng et al., 2013). Our results showed that AC at a concentration of $0.008 \%$ induced cell proliferation into friable callus, which is a characterization of embryogenic callus (Table 1). Thereafter, up to 2 months, some friable calli developed into somatic embryos or roots (Figure 1B). Kaouther et al., (2011) reported that $\mathrm{AC}$ at $0.3 \%$ was effective in controlling oxidation and improving the percentage of callus induction in palms. Therefore, owing to the strong adsorptive properties exhibited by AC in tissue culture media, it could remove the growth-inhibitory substances produced by plant tissue (Cheng et al., 2013). Moreover, AC adsorbed not only the plant growth-inhibitory substances in the medium, but also the plant growth regulators and nutrients (Liu, 1993). Thus, the increasing of $\mathrm{AC}$ effects on the survival explant. This could also explain why the treatment of 2,4-D + BA with a concentration of AC beyond $0.08 \%(\mathrm{w} / \mathrm{v})$, to $0.01 \%$ and $1 \%$, showed a decreasing trend of cell proliferation into callus formation in surviving explants (Table 1).

\section{Effects of picloram with or without 2,4-D and BA on callus induction in C. arabica "Catimor CIFC 7963" leaf explants}

The highest fresh weight of 4-month-old callus ( $0.32 \pm 0.06 \mathrm{~g} / \mathrm{explant})$ was obtained for MS medium supplemented with $1 \mu \mathrm{M} 2,4-\mathrm{D}+5 \mu \mathrm{M}$ BA, containing $10 \mathrm{mM}$ picloram (treatment $\mathrm{G}$ ). In addition, treatment $\mathrm{H}$ showed that $10 \mathrm{mM}$ picloram was the sole plant growth regulator, which affected cell division without the presence of cytokinin hormones (Table 2). This result was supported by a previous report that $4 \mu \mathrm{M}$ picloram as the sole plant growth regulator induces callus formation in C. arabica "Rubi", "Catuaí vermelho 81", and "IAPAR 59" (Cid et al., 2004). According to Ozel et al., (2018), a high concentration of picloram affects the root cells of Allium cepa, which exhibited a decreased MI and mitotic abnormalities such as anaphase bridges, C-mitosis, multipolarity, fragments, and lagging chromosomes and polyploidy. We found that addition of $10 \mathrm{mM}$ picloram resulted in high rate of callus formation in C. arbica "Catimor CIFC 7963" and relatively unaffected calli cells, with the frequency of mitotic abnormality limited to around $1 \%$. Picloram produced a larger size of friable calli compared with the MS medium supplemented with $1 \mu \mathrm{M} 2$, 4-D + $5 \mu \mathrm{M}$ BA (Figure 1A and 1C). This result revealed that picloram served as a superior auxin than 2, 4-D hormone. This could be due the more effective uptake and rapid mobilization of picloram at the target sites (Karun et al., 2004). The superior effect of picloram for embryogenic callus induction has been reported in many plants such as palm (Elaeis guineensis Jacq.), cherry (Prunus incisa Thunb.), kodo millet (Paspalum scrobiculatum L.), and C. arabica (Cid et al., 2004; Kaur and Kothari, 2004; Kaouther et al., 2011; Jayanthi et al., 2015). 


\section{Cytological and MI analysis of calli cells ( 2 and 4 months old)}

The highest proportion of cells was seen in prophase, whereas the number of calli cells in metaphase, anaphase, and telophase was relatively low across all media (Table 3). Furthermore, we found that the rate of division of 4-month-old calli cells decreased at prophase in treatments $\mathrm{G}$ and $\mathrm{H}$ compared with treatments $\mathrm{B}$ and C. Picloram treatments decreased the rate of prophase activity, thereby diminishing the MI. The reduction in MI could have been due to blocking of DNA synthesis at the G1 or S phase (Schneiderman et al., 1971; Sudhakar et al., 2001) or blocking of the G2 phase (Van't, 1968). Our results showed that the reduction in the MI was clearly related to long-term culture, as well as the cytotoxic effect of picloram and 2,4-D, resulting in three types of structural aberrations: binucleated cells, micronuclei in binucleated cells, and vagrant chromosome cells (Figuure 2G-I).

The mitotic aberration frequency was $1 \%$ (data not shown). According to Landey et al. (2013), the variant frequency increased in embryogenic suspensions of $C$. arabica after 6 months of culture in a medium containing $4.52 \mathrm{mM} 2,4-\mathrm{D}$, while after 12 months, the frequency reached $25 \%$. Thereafter, they observed SV in 11- and 27-month-old embryogenic callus cultures, which affected the aneuploidy regenerated plants. This result suggested that cell culture ageing is highly mutagenic in coffee and chromosomal rearrangements are directly linked to SV (Landey et al., 2015). Our results showed that $10 \mathrm{mM}$ picloram induced a rapid rate of cell division (Table 1 and Figure 1 C-D). As a consequence, there was a disorganized rapid growth phase in the callus, which contributed to the SV (Karp, 1994; Rani and Raina, 2000). This result was supported by the finding of a previous report that $1 \mathrm{mg} / \mathrm{L}$ picloram shows a significantly higher induction rate than $0.1 \mathrm{mg} / \mathrm{L}$ IAA and $0.1 \mathrm{mg} / \mathrm{L}$ IBA, but the SEs obtained show teratological abnormalities such as fused or polycotyledonary embryos (Kaouther et al., 2011). We demonstrated that the effect of culture age was associated with prolonged exposure to $10 \mathrm{mM}$ picloram. Many altered mechanisms, observed during the mitosis of calli cells of C. arabica, can produce chromosome alterations such as polyploidy, aneuploidy, sticky chromosomes, double prophases, and lagging chromosomes (MenéndezYuffá et al., 2000). Our results showed that cells of $C$. arabica "Catimor CIFC 7963 " with a micronucleus or binucleated cells and vagrant chromosome cells would be differentiated into polyploid and aneuploid plants, respectively.

SV detection has used to verify ploidy instability in embryogenic cells of C. arabica in vitro using flow cytometry (FCM) (Clarindo et al., 2012). This report revealed that FCM was able to detect the non-true-to-type calli cells (4 months old), and highlighted the octaploid or aneuploid cells. Therefore, these authors recommended a culture age limit of 4 months for true-to-type mass propagation of $C$. arabica cell suspensions (Clarindo et al., 2012). Similarly, our results indicated that the 4-month-old calli cells of $C$. arabica "Catimor CIFC 7963 " exposed to $10 \mathrm{mM}$ picloram showed mitotic aberrations. However, to the 
best of our knowledge, the 4-month-old friable calli cultured on MS medium supplemented with $1 \mu \mathrm{M} 2,4-\mathrm{D}+5 \mu \mathrm{M} \mathrm{BA}+0.008 \%$ AC did not have cytotoxic effect on cells. In contrast, treatment with $1 \mu \mathrm{M} 2,4-\mathrm{D}+5 \mu \mathrm{M} \mathrm{BA}+10 \mathrm{mM}$ picloram affected 4-month-old calli cells, and resulted in a mitotic aberration frequency of $1 \%$ compared with the 3-month-old embryogenic cell suspension of C. arabica, which showed a frequency of $1.3 \%$ (Etienne and Bertrand, 2003). Moreover, our culture medium resulted in a lower frequency of SV (1\%) than the embryogenic calli of $C$. arabica "Catimor CIFC 7963" (25\%) cultured on $1 / 2 \mathrm{MS}$ supplemented with $1 \mathrm{mg} / \mathrm{L} 2,4-\mathrm{D}+8 \mathrm{mg} / \mathrm{L} \mathrm{BA}$, followed by transfer to the same medium containing $0.8 \mathrm{mg} / \mathrm{L}$ NAA for 3 months (Menéndez-Yuffá et al., 2000).

\section{CONCLUSION}

The results of this study showed that leaf explants of $C$. arabica "Catimor CIFC 7963" could be induced to form compact and friable calli on MS medium supplemented with $1 \mu \mathrm{M} 2,4-\mathrm{D}+5 \mu \mathrm{M}$ BA. Furthermore, friable calli were produced on MS media supplemented with $1 \mu \mathrm{M} 2,4-\mathrm{D}+5 \mu \mathrm{M} \mathrm{BA}+0.008 \%$ $\mathrm{AC}(\mathrm{w} / \mathrm{v}), 1 \mu \mathrm{M} 2,4-\mathrm{D}+5 \mu \mathrm{M} \mathrm{BA}+10 \mathrm{mM}$ picloram, or $10 \mathrm{mM}$ picloram. Our results revealed that $\mathrm{AC}$ at a concentration of $0.008 \%$ induced cell proliferation into friable callus at a slower rate than $10 \mathrm{mM}$ picloram. However, cytotoxic effects of $10 \mathrm{mM}$ picloram in this experiment caused mitotic aberrations in the long-term culture (4 months old). In contrast, $0.008 \%$ AC did not show any cytotoxic potential in cultured calli during the 4 months. Based on these results, we recommended an upper limit of 4 months for true-to-type mass propagation of C. arabica "Catimor CIFC 7963" friable calli with $10 \mathrm{mM}$ picloram. The friable calli should be induced into SEs within 2-3 months, and the obtained seedlings would show a decreased SV. Given that SV was observed in the cytological study, it is advisable to conduct further analyses of the SEs using other methods, such as DNA molecular markers or chromosome count methods. These will confirm the genetic stability of the coffee plant SEs.

\section{ACKNOWLEDGEMENTS}

The authors gratefully acknowledge the grant provided by the Faculty of Liberal Arts and Science, Kasetsart University Kamphaeng Saen Campus, Thailand and for the necessary facilities provided by the Department of Genetics. 


\section{REFERENCES}

Arora, K., Sharma, M., Kapoor, K., Srivastana, A., and Sharma, A.K. 2013. Cytological analysis of nodal stem segment and callus regenerated plantlets of Azadirachta indica A. Juss. (Neem). In: Kumar, A., and Shekhawat, N.S., editors. Plant tissue cultures and molecular markers, their role in improving crop productivity. I.K. International Publishing House Pvt. Ltd., India. p. 121-132.

Chee, P.P., and Tricoli, D.M. 1988. Somatic embryogenesis and plant regeneration from cell suspension cultures of Cucumis sativus L. Plant Cell Reports. 7: 274-277. https://doi.org/10.1007/BF00272541

Cheng, Y., Ma, R-.1., Jiao, Y-.S., Qiao, N., and Li., T-.T. 2013. Impact of genotype, plant growth regulators and activated charcoal on embryogenesis induction in microspore culture of pepper (Capsicum annuum L.). South African Journal of Botany. 88: 306-309. https://doi.org/10.1016/j.sajb.2013.08.012

Cid, L.P.B., Cruz, A.R.R., and Castro, L.H.R. 2004. Somatic embryogenesis from three coffee cultivars: 'Rubi', 'Catuaí Vermelho 81' and 'IAPAR 59'. Horticulture Science. 39(1): 130-131. https://doi.org/10.21273/HORTSCI. 39.1 .130

Clarindo, W.R., Carvalho, C.R., and Mendonc, M.A.C. 2012. Ploidy instability in long-term in vitro cultures of Coffea arabica L. monitored by flow cytometry. Plant Growth Regulation. 68: 533-538. https://doi.org/10.1007/ s10725-012-9740-0

Etienne, H., and Bertrand, B. 2003. Somaclonal variation in Coffea abrabica: effects of genotype and embryogenic cell suspension age on frequency and phenotype of variants. Tree Physiology. 23: 419-426. https://doi.org/10. 1093/treephys/23.6.419

Etienne, H., Bertrand, B., Dechamp, E., Maurel, P., Georget, F., Guyot, R., and Breitler, J.-C. 2016. Are genetic and epigenetic instabilities of plant embryogenic cells a fatality? the experience of coffee somatic embryogenesis. Human Genetics and Embryology. 6(1): 1-5. https:// doi.org/10.4172/2161-0436.1000136

Freund, J.F., and Wilson, W.J. 2003. Statistical Methods. London: Academic Press.

Jayanthi, M., Susanthi, B., Mohan, N.M., and Mandal, P.K. 2015. In vitro somatic embryogenesis and plantlet regeneration from immature male inflorescence of adult dura and tenera palms of Elaeisguin eensis (Jacq.). SpringerPlus. 4: 256. https://doi.org/10.1186/s40064-015-1025-4

Jähne, A., Lazzeri, P.A., Jäger Gussen, M., and Lörz, H. 1991. Plant regeneration from embryogenic cell suspensions derived from anther cultures of barley (Hordeum vulgare L.). Theoretical and Applied Genetics. 82: 74-80. https://doi.org/10.1007/BF00231280 
Kaouther, B.M., Nadhra, E., Ahlem, C., Jemmali, A., and Druart, P. 2011. In Vitro picloram induced somatic embryogenesis from leaflets of cherry (Prunus incise Thunb.). Journal of Life Sciences. 5: 913-920.

Karp, A. 1994. Origins, causes and uses of variation in plant tissue cultures. In: Vasil, I.K., and Thorpe, T.A., editors. Plant Cell and Tissue Culture. Dordrecht: Kluwer Academic Publishers. p.139-152.

Karun, A., Siril, E.A., Radha, E., and Parthasarathy, V.A. 2004. Somatic embryogenesis and plantlet regeneration from leaf and inflorescence explants of a recanut (Area catechu L.). Current Science. 86: 1623-1628.

Kaur, P., and Kothari, S.L. 2004. In vitro culture of kodo millet: influence of 2, 4-D and picloram in combination with kinetin on callus initiation and regeneration. Plant Cell, Tissue Organ Culture. 77(1): 73-79. https://doi. org/10.1023/B:TICU.0000016505.20448.44

Lambé, P., Mutambel, H.S.N., Fouche, J.G., Deltour, R., Foidart, J.M., and Gaspar, T. 1997. DNA methylation as a key process in regulation of organogenic totipotency and plant neoplastic progression. In Vitro Cellular and Developmental Biology-Plant. 33(3): 155-162. https://doi.org/10712690/97

Landey, R.B., Cenci, A., Georget, F., Bertrand, B., Camayo, G., Dechamp, E., Herrera, J.C., Santoni, S., Lashermes, P., Simpson, J., et al. 2013. High genetic and epigenetic stability in Coffea arabica plants derived from embryogenic suspensions and secondary embryogenesis as revealed by AFLP, MSAP and the phenotypic variation rate. PLOS ONE. 8(2): https://doi.org/10.1371/journal.pone.0056372

Landey, R.B., Cenci, A., Guyot, B., Bertrand, B., Georget, F., Dechamp, E., Herrera, J-.C., Aribi, J., Lashermes, P., and Etienne, H. 2015. Assessment of genetic and epigenetic changes during cell culture ageing and relations with somaclonal variation in Coffea arabica. Plant Cell, Tissue Organ Culture. 122: 517-531. https://doi.org/10.1007/s11240-015-0772-9

Larkin, P.J., and Scowcroft, W.R. 1981. Somaclonal variation: a novel source of variability from cell cultures for plant improvement. Theoretical and Applied Genetics. 60: 197-214. https://doi.org/10.1007/BF02342540

Liu, M.C. 1993. Factors affecting induction, somatic embryogenesis and plant regeneration of callus from cultured immature inflorescences of sugarcane. Journal of Plant Physiology. 141(6): 714-720. https://doi.org/10.1016/ S0176-1617(11)81580-4

Lu, S., Wang, Z., Peng, X., Guo, Z., Zhang, G., and Liebao, H. 2006. An efficient callus suspension culture system for triploid bermudagrass (Cynodon transvaalensis x $C$. dactylon) and somaclonal variations. Plant Cell, Tissue and Organ Culture. 87(1): 77-84. https://doi.org/10.1007/s11240-0069138-7 
Menéndez-Yuffá, A., Da Silva, R.F., Rios, L., and Enrech, de N.X. 2000. Mitotic aberrations in coffee (Coffea arabica cv. 'Catimor') leaf explants and their derived embryogenic calli. Electronic Journal of Biotechnolgy. 3(2): 161 166. https://doi.org/10.2225/vol3-issue2-fulltext-1

Murashige, T., and Skoog, F. 1962. A revised medium for rapid growth and bioassays with tobacco tissue cultures. Physiologia Plantarum. 15: 473497. https://doi.org/10.1111/j.1399-3054.1962.tb08052.x

Ozel, C.A., Ozkul, M., Unal, F., and Yuzbasioglu, D. 2018. Evaluation of genotoxicity of picloram by Allium test in plant tissue culture. Fresenius Environmental Bulletin. 27(12): 8133-8138.

Potapova, T., and Gorbsky, G.J. 2017. The consequences of chromosome segregation errors in mitosis and meiosis. Biology. 6(12): 12. https://doi.org/10.3390/biology6010012

Raha, S., and Roy, S.C. 2003. Chromosome stability in culture derived plants of Holarrhena antidysenterica wall and study of differentiating tissues using SEM. Caryologia. 56(3): 329-335. https://doi.org/10.1080/00087114. 2003.10589342

Rani, V., and Raina, S. 2000. Genetic fidelity of organized meristem-derived micropropagated plants: a critical reappraisal. In Vitro Cellular and Developmental Biology-Plant. 36: 319-330. https://doi.org/10.1007/ s11627-000-0059-6

Rival, A., Beulé, T., Barre, P., Hamon, S., Duval Y., and Noirot, M. 1997. Comparative flow cytometric estimation of nuclear DNA content in oil palm (Elaeis guineensis Jacq.) tissue cultures and seed-derived plants. Plant Cell Reports. 16(12): 884-887. https://doi.org/10.1007/ s002990050339

Shcneiderman, M.H., Dewey, W.C., and Highfield, D.P. 1971. Inhibition of DNA synthesis on synchronized chinese hamster cell treated in G1 with cycloheximide. Experimental Cell Research. 67: 147-155. https://doi.org/ 10.1016/0014-4827(71)90630-6

Silva, R.F., Hermoso-Gallardo, L., and Menéndez-Yuffá, A. 2005. Primary and secondary somatic embryogenesis in leaf sections and cell suspension of Coffea arabica cv. Catimor. Interciencia. 30(11): 694-698.

Sudhakar, R., Ninge, G.K.N., and Venu, G. 2001. Mitotic abnormalities induced by silk dyeing industry effluents in the cell of Allium cepa. Cytologia. 66: 235-239. https://doi.org/10.1508/cytologia.66.235

Sáenz, L., Herrera-Herrera, G., Uicab-Ballote, F., Chan, J.L., and Oropeza, C. 2010. Influence of form of activated charcoal on embryogenic callus formation in coconut (Cocos nucifera). Plant Cell, Tissue Organ Culture. 100: 301-308. https://doi.org/10.1007/s11240-009-9651-6

Thomas, T.D. 2008. The role of activated charcoal in plant tissue culture. Biotechnology Advances. 26: 618-631. https://doi.org/10.1016/j.biotechadv. 2008.08.003. Epub 2008 Aug 22 
Van Winkle, S.C., and Pullman, G.S. 2003. The combined impact of pH and activated carbon on the elemental composition of a liquid conifer embryogenic tissue initiation medium. Plant Cell Report. 22: 303-311. https://doi.org/10.1007/s00299-003-0686-6

Van Winkle, S.C., Johnson, S., and Pullman, G.S. 2003. The impact of gelrite and activated carbon on the elemental composition of two conifer embryogenic tissue initiation media. Plant Cell Reports. 21: 1175-1182. https://doi. org/10.1007/s00299-003-0637-2

Van't Hof, J. 1968. The action of IAA and kinetin on the mitotic cycle of proliferative and stationary phase excised root meristem. Experimental Cell Research. 51: 167-176. https://doi.org/10.1016/0014-4827(68)901675Von

Von Aderkas, P., and Bonga, J.M. 2000. Influencing micropropagation and somatic embryogenesis in mature trees by manipulation of phase change, stress and culture environment. Tree Physiology. 20: 921-928. https://doi.org/10.1093/treephys/20.14.921 